\title{
RELEVANSI NILAI DAN KEMUNGKINAN DETERIORASI: KAJIAN LITERATUR SISTEMATIK
}

\author{
Randy Kuswanto \\ Sekolah Tinggi Ilmu Ekonomi Wiyatamandala \\ randy@wym.ac.id
}

\begin{abstract}
The paper presents the review of the value relevance literatures used Ohlson model (1995). The popularity of value relevance topic nowadays is principally driven by the adoption IFRS which changed how companies measure its income and assets. Although this topic is still in debate whether it useful or not, this paper tried to conclude a summary from many prior value relevance researches. First, I seek to review some of the significant literature on value relevance during 2009-2019. The emphasis is on results and empirical contributions relating incremental value relevance. The second part of this paper is discussion about eight different studies from more than 10 countries about evidence of value relevance phenomenon in their setting. This paper finds that the concept of value relevance really exists in many countries but it is deteriorating / declining over the period. Further research could test other information to prevent this deterioration of value relevance such as future prospect attributes rather than historical information only.
\end{abstract}

Keywords: Value Relevance, Ohlson Model, Stock Price

\section{PENDAHULUAN}

Di dalam berbagai literatur akuntansi, salah satu topik populer yang selalu dibahas oleh berbagai peneliti ialah bagaimana menghubungkan angkaangka dalam laporan keuangan dengan harga saham. Hubungan antara laporan keuangan dan harga saham merupakan sebuah kajian klasik yang biasa disebut relevansi nilai (Alfraih, 2016). Konsep relevansi menunjukkan informasi yang berasal dari proses akuntansi seharusnya dapat digunakan penggunanya untuk mempengaruhi pengambilan keputusan investasi.

Istilah relevansi nilai mulai digunakan sejak munculnya penelitian Ball and Brown, (1968) dan Beaver, (1968). Namun topik relevansi nilai mulai menjadi populer sejak penelitian Ohlson (Ohlson, J.A., 1995. Earnings, book values, and dividends in security valuation). Pada artikelnya, Ohlson membuat formula matematis yang menghubungkan angka-angka akuntansi seperti laba, nilai buku, dividen terhadap harga saham. Penelitian ini kemudian menjadi topik seminal yang 
dikritisi dan diuji kembali oleh para peneliti (Barth, 2001; Beaver, 2002; Lev \& Zarowin, 1999).

Relevansi nilai memiliki dua asumsi utama yaitu netralitas risiko dan surplus bersih. Model Ohlson merupakan formula yang menghubungkan antara angka-angka akuntansi dengan harga saham. Model tersebut mengasumsikan investor dengan risiko netral akan selalu mempertahankan harga dan menghindari informasi yang bernilai risiko sehingga tingkat bebas risiko menjadi diskonto dalam perhitungan return saham (Kumari, 2017). Asumsi kedua yaitu surplus bersih merupakan bagian dari sistem akuntansi dimana nilai buku sekarang sama dengan nilai buku periode sebelumnya ditambah laba dan dikurangi dividen. Poin pentingnya ialah dividen mengurangi nilai buku perusahaan bukan mengurangi laba sehingga sistem ini disebut sebagai surplus bersih. Hal ini membuat laba perusahaan sebagai estimator relevansi nilai tidak terdistraksi dengan aktivitasaktivitas yang tidak berhubungan dengan laba atau profit dan menjadikan nilai laba yang dihasilkan benar-benar merepresentasikan nilai yang diperoleh akuntansi. Angka akuntansi yang digunakan dalam model relevansi nilai ialah nilai buku dan laba perusahaan. Kedua angka ini mereperesentasikan nilai bawah (bottom line) dari masingmasing laporan keuangan -laporan laba rugi dan laporan posisis keuangan. Berbagai penelitian mencoba membuktikan model relevansi nilai. Kuswanto (2017) menguji relevansi nilai dengan mengkaji dampak kondisi laba perusahaan terhadap kekuatan relevansi nilai di Indonesia. Hasil penelitiannya menunjukkan bahwa pada kondisi laba positif, relevansi nilai laba perusahaan menjadi lebih kuat. Sedikit kontradiktif, pada kondisi laba positif pula, relevansi nilai buku perusahaan menjadi lebih lemah. Dengan penelitian tersebut menunjukkan bahwa walaupun merepresentasikan angka laporan keuangan, laba dan nilai buku tidak selalu bersifat koheren. Selain laba dan nilai buku, beberapa literatur seperti Barth et. al (1999) dan Habib (2008) berargumentasi terkait pengikutsertaan nilai arus kas operasi sebagai bagian dari valuasi perusahaan. Laba merupakan nilai yang "tidak jelas" (illdefined) dan terbentuk dari banyak persepektif (Bepari et al., 2013). Laba cenderung menjadi objek yang sering dimanipulasi sementara arus kas lebih 
sulit untuk dimodifikasi karena melibatkan unsur fisik yang tidak akrual. Walaupun demikian, di beberapa negara arus kas operasi memang bukan merupakan subjek keuangan signifikan dan efeknya tidak dapat meningkatkan relevansi nilai secara signifikan (Charitou et al., 2001; Martinez, 2003; dan Ebrahimi, 2010). Perdebatan antara penggunaan arus kas operasi atau laba masih terus berlanjut hingga sekarang dan penelitian empiris menyajikan hasil yang berbeda-beda. Salah satu alasan mengapa relevansi nilai menjadi topik yang selalu relevan ialah perubahan standar akuntansi. Pada rentang 20032009 standar akuntansi yang dibentuk oleh International Accounting Standar Board (IASB) mulai secara perlahan digunakan di berbagai negara. Standar yang dikenal dengan sebutan International Financial Reporting Standards (IFRS) secara masif mensubtitusi standar umum yang sebelumnya digunakan (Generally Accepted Accounting PrinciplesGAAP). Salah satu perbedaan signifikan selain penggunaan fair value dalam penilaian aset ialah pendefinisian laba komprehensif. Elemen pendapatan komprehensif lain yang sebelumnya dilaporkan secara surplus bersih kini harus melalui penyajian awal di dalam laporan laba rugi sebagai penambah/pengurang laba. Bila nilai akhir (bottom line) perusahaan awalnya ialah laba setelah pajak (net income), sekarang menurut standar IFRS perusahaan perlu mengajikan seksi tambahan yang memuat pendapatan komprehensif lainnya (other comprehensive income-OCI) setelah laba bersih dan membentuk bottom line baru yaitu laba komprehensif (comprehensive income). Pembentukan nilai ini memicu pengujian kembali kekuatan relevansi nilai. Jika dulu asumsi surplus bersih digunakan untuk menguji relevansi nilai, dengan adanya standar akuntansi baru akan mengubah tatanan penyusunan laba perusahaan yang menarik untuk diuji secara empiris. Tidak hanya laba, bagian ekuitas secara langsung juga dipengaruhi dengan adanya prinsip nilai wajar. Berbagai instrumen investasi dan aset tetap kini harus diakui pada nilai wajar sesuai tanggal pelaporan keuangan. Adanya keuntungan atau kerugian yang belum terealisasi harus tetap dicatatkan sebagai elemen penambah atau pengurang jenis aset tersebut yang berdampak pada peningkatan atau penurunan ekuitas. 
Dengan perubahan ini relevansi nilai menjadi topik hangat yang menjadi salah satu model populer yang diteliti dalam rentang 2005-2015.Selanjutnya penelitian ini akan dijelaskan dalam

\section{TELAAH LITERATUR}

Informasi akuntansi disebut memiliki relevansi nilai apabila berhubungan secara statistik dengan harga pasar suatu saham (Bin Khidmat et al., 2019). Studi mendalam mengenai relevansi nilai sudah banyak dipublikasikan oleh berbagai peneliti di berbagai negara. Hasil penelitian juga memiliki hasil yang beragam baik bersifat konfirmasi dan kontradiksi. Berbagai teori yang terkait dengan relevansi nilai yaitu teori pasar efisien, teori surplus bersih, dan teori pengungkapan.

\section{Teori Pasar Efisien}

Konsep dasar dari pasar efisien adalah bahwa pasar dikatakan efisien apabila pasar secara cepat merefleksikan seluruh informasi yang ada ke harga suatu saham sehingga tidak ada investor yang memperoleh return tak normal (Gumanti, 2002). Terdapat tiga bentuk pasar efisien yaitu (1) hipotesis pasar efisien bentuk lemah (weak form of the efficient market hypothesis), beberapa bagian yaitu bagian (ii) telaah literatur, bagian (iii) metodologi penelitian, bagian (iv) hasil dan analisis, dan bagian terakhir yaitu kesimpulan.

hipotesis pasar efisien bentuk setengah kuat (semi-strong form of the efficient market hypothesis), dan (3) hipotesis pasar efisien bentuk kuat (strong form of the efficient market hypothesis). Teori pasar efisien erat kaitannya dengan relevansi nila karena jika pasar tidak efisien maka relevansi nilai akan menurun (Bepari et al., 2013). Hargaharga saham akan gagal mencerminkan kondisi keuangan perusahaan dan akan mendistorsi informasi tersebut sehingga akan mempengaruhi harga saham. Pasar yang efisien akan membuat harga saham merefleksikan konten dari laporan keuangan dan jika relevansi nilai tinggi, maka investor tidak dapat mendapatkan return tak normal sebagai akibat cepatnya reaksi pasar secara agregat.

\section{Teori Surplus Bersih}

Teori surplus bersih dicetuskan pertama kali oleh James A Ohlson pada tahun 1995. Teori ini didasari pada konsep nilai dalam teori ekonomi 
neoklasik. Teori surplus bersih menjelaskan hubungan antara data akuntansi dan nilai perusahaan dengan mengasumsikan investor memiliki keyakinan dan preferensi yang homogen (Kuswanto, 2017). Teori surplus bersih merupakan kontra teori dari teori surplus kotor. Teori surplus kotor merupakan pengaturan sistem pengakuan item laporan keuangan dimana untuk mengubah nilai kepemilikan (aset bersih) perusahaan, harus melewati laporan laba rugi terlebih dahulu. Contohnya, untuk mengakui penambahan kas perusahaan maka perlu dilaporkan dalam laporan laba rugi sebagai pendapatan. Penambahan atau pengurangan ini tidak dapat dilakukan secara i sebagai pendapatan. Penambahan atau pengurangan ini tidak dapat dilakukan secara bypass kecuali dividen. Dividen mengurangi kekayaan perusahaan tanpa perlu melewati laporan laba rugi. Konsep dividen yang seperti ini dikenal dengan istilah surplus bersih. Dengan teori surplus bersih maka formula perhitungan nilai buku menjadi lebih sederhana yaitu nilai buku sekarang merupakan hasil operasi dari nilai buku periode sebelum ditambah laba bersih dikurangi dividen. Relevansi nilai memerlukan teori ini untuk pembentukan nilai laba dan nilai buku ekuitas perusahaan yang menjadi proksi dari angka akuntansi itu sendiri.

\section{Teori Pengungkapan}

Pengungkapan merupakan bagian penting dari akuntansi karena tujuan utama dari akuntansi sebagai teknologi ialah menghasilkan informasi yang bermanfaat bagi penggunanya. Informasi yang diungkapkan dapat memicu proses pengambilan keputusan investasi. Standar akuntansi merupakan aturan minimum sebagai sebuah persyaratan minimal bagaimana suatu informasi akuntansi diungkapkan. Pengukuran pengungkapan dapat dilakukan dengan berbagai cara dengan asumsi implisit tentang kualitas pengungkapan yang diukur. Urquiza et. al (2010) menunjukkan bahwa besarnya pengungkapan menjadi satu-satunya determinan yang selalu signifikan terlepas atribut pengukuran lainnya yang sedang diukur. Teori pengungkapan seharusnya lebih menaruh perhatian pada atribut informasi yang diukur seperti bagaimana suatu informasi diukur. Teori pengungkapan juga terkait dengan teori pensinyalan. Menurut teori 
pensinyalan, perusahaan akan mengungkapkan informasi baik lebih cepat untuk menunjukkan kepada para

\section{METODE PENELITIAN}

\section{Kajian Literatur}

Metode yang digunakan dalam penelitian ini adalah kajian literatur sistematik. Menurut Dudovskiy (2018), kajian literatur adalah seperangakt tulisan yang bersifat mengkritisi berbagai literatur dan menyimpulkan menjadi sebuah penelitian. Sedangkan, kajian literatur sistematik memerlukan kajian yang lebih kuat dan pendekatan yang lebih dalam dengan menggunakan timeframe pada literatur-literatur yang dikaji. Kajian literatur sistematik sendiri terbagi dua yaitu kajian literatur analisis-meta dan sintesis-meta. Penelitian ini menggunakan kategori stakeholder bahwa perusahaan memiliki kinerja yang baik.

sintesis-meta karena literatur akan disajikan dengan menggunakan teknik non-statistikal. Dengan teknik ini, literatur akan diintegrasikan, dievaluasi, dan diinterpretasikan temuan dari berbagai riset-riset kualitatif. Teknik ini sering digunakan untuk melaksanakan riset dengan pendekatan induktif. Literatur yag dipilih dalam penelitian ini adalah literaur yang meneliti dan membahas topik relevansi nilai dari berbagai bidang. Artikel yang dipilih ialah artikel-artikel yang diterbitkan dalam satu dekade terakhir (20092019). Berikut adalah artikel-artikel yang akan dianalisis sebagai sebuah kajian literatur.

Tabel 1. Riset Mengenai Relevansi Nilai

$\begin{array}{ccc}\text { No } & \text { Nama Peneliti dan Tahun Penelitian } & \text { Judul Penelitian } \\ 1 & \text { Adibah Jamaluddin, Nor'Azam Mastuki, } & \text { Corporate governance reform } \\ & \text { dan Asyari Elmiza Ahmad (2009) } & \text { and the value relevance of } \\ & \text { equity book value and } \\ & \text { earnings in malaysia } \\ & \text { Alireza Vafaei, Dennis Taylor, Kamran } & \text { The value relevance of } \\ & \text { intellectual capital } \\ & \text { disclosures }\end{array}$


Tabel 2. Riset Mengenai Relevansi Nilai

\begin{tabular}{|c|c|c|}
\hline No & $\begin{array}{c}\text { Nama Peneliti dan Tahun } \\
\text { Penelitian }\end{array}$ & Judul Penelitian \\
\hline 3 & $\begin{array}{c}\text { Khokan Bepari, Sheikh F Rahman, } \\
\text { dan Abu Taher Mollik (2013) }\end{array}$ & $\begin{array}{c}\text { Value relevance of earnings and } \\
\text { cash flows during the global } \\
\text { financial crisis }\end{array}$ \\
\hline 4 & Mishari M Alfraih (2016) & $\begin{array}{c}\text { Have financial statements lost } \\
\text { their relevance? Empirical } \\
\text { evidence from the frontier } \\
\text { market of Kuwait }\end{array}$ \\
\hline 5 & $\begin{array}{l}\text { Ali Ahmadi dan Abdelfettah Bouri } \\
\qquad(2018)\end{array}$ & $\begin{array}{c}\text { The accounting value relevance } \\
\text { of earnings and book value: } \\
\text { Tunisian banks and financial } \\
\text { institutions }\end{array}$ \\
\hline 6 & $\begin{array}{l}\text { Arthur Joseph Avwokeni, Khaled } \\
\text { Hussainey, dan Collins G Ntim } \\
\text { (2018) }\end{array}$ & $\begin{array}{c}\text { On the value relevance } \\
\text { argument: do market } \\
\text { participants place a premium on } \\
\text { future prospects of the firm? }\end{array}$ \\
\hline 7 & $\begin{array}{c}\text { Hesham I Almujamed dan Mishari } \\
\text { M Alfraih (2019) }\end{array}$ & $\begin{array}{c}\text { Value relevance of earnings and } \\
\text { book values in the Qatari Stock } \\
\text { Exchange }\end{array}$ \\
\hline 8 & $\begin{array}{l}\text { Waas Bin Khidmat, Man Wang, } \\
\text { dan Sadia Awan (2019) }\end{array}$ & $\begin{array}{c}\text { The value relevance of } R \& D \text { and } \\
\text { free cash flow in an efficient } \\
\text { investment setup: Evidence from } \\
\text { Chinese A-listed firms }\end{array}$ \\
\hline
\end{tabular}

\section{Metode Pengumpulan Data}

Pengumpulan data dilakukan dengan dengan metode dokumentasi. Data sekunder yang diperlukan adalah artikel-artikel yang relevan dengan topik penelitian ini. Artikel dapat diakses secara daring melalui website emerald insight, science direct, maupun EBSCO.

\section{Desain Penelitian}

Penelitian ini akan menelaah artikel relevansi nilai secara terpisah dan multi- 
topik. Terpisah berarti analisis akan membahas artikel secara satu per satu berdasarkan tahun terdahulu. Multitopik berarti bahwa peneliti tidak mengontrol sub-topik penelitian terkait satu sub-topik tertentu. Subtopik yang akan dibahas antara lain mengenai tata kelola perusahaan, modal intelektual,

\section{PEMBAHASAN}

1. Corporate governance reform and the value relevance of equity book value and earnings in malaysia - (Jamaluddin et al., 2009)

Seperti model klasik relevansi nilai, penelitian ini menggunakan nilai buku per saham dan laba per saham sebagai variable independen dan harga saham sebagai variable dependen. Penelitian yang dilakukan di Bursa Efek Malaysia tahun 1999-2001 ini juga mempertimbangkan efek dari tata kelola perusahaan berdasarkan diterbitkannya Malaysian Code of Corporate Governance (MCCG). Temuan penelitian ini mengindikasikan bahwa angka-angka laporan keuangan memiliki relevansi krisis ekonomi, arus kas bebas, dan riset dan pengembangan. Diakhir pembahasan peneliti akan membuat ringkasan mengenai keterkaitan temuan, kritik, dan argument mengenai relevansi nilai selama satu dekade berdasarkan artikel yang dibahas sebelumnya.

nilai secara umum terhadap harga saham perusahaan. Temuan tersebut menunjukkan bahwa perubahan aturan yang bersifat makro yang dialami suatu negara tidak memiliki dampak kuat terhadap hubungan relevansi yang terjadi. Dengan nilai p-value yang signifikan pada level 0,05 untuk variable EPS dan BVPS membuktikan bahwa pasar modal di Malaysia memiliki relevansi nilai cukup walaupun nilai R2 hanya 0,246 saja. Dengan demikian, masih banyak faktor lagi yang mempengaruhi harga saham selain angka-angka yang ada dalam laporan keuangan Terkait efek moderasi dari tata kelola perusahaan, masih banyak perusahaan di Malaysia yang tidak memenuhi tujuan inti 
dari MCCG tetapi hanya sekedar memenuhi persyaratan minimum saja. Walaupun penelitian ini hanya menggunakan tiga periode saja, namun penelitian ini cukup menggambarkan bagaimana relevansi nilai tetap bisa terjadi pada kondisi pasca krisis ekonomi dan perubahan tata kelola. Jika dilihat dari data, efek moderasi tidak terjadi pada model penelitian. Penggunaan aturan tata kelola belum bisa meningkatkan hubungan dan kualitas relevansi nilai itu sendiri sehingga elemen tata kelola belum mampu menjadi factor kunci dalam peningkatan relevansi nilai.

2. The value relevance of intellectual capital disclosures (Vafaei et al., 2011)

Studi ini dilakukan dengan sampel dari 4 negara yaitu Inggris Raya, Australia, Hong Kong, dan Singapura. Artikel ini mengaitkan efek dari pengungkapan modal intelektual terhadap relevansi nilai dengan peran sebagai variable moderasi. Pengungkapan modal intelektual dilakukan dengan analisis konten dengan objek laporan tahunan. Selain ingin menguji efek modal intelektual, penelitian ini juga memiliki tujuan utama untuk menguji peningkatan relevansi nilai akibat perubahan standar akuntansi IFRS untuk pertama kalinya di empat negara tersebut. Model pertama yang diuji dalam penelitian ini adalah menggunakan nilai buku dan laba per saham dengan pengukuran yang berbeda antara GAAP dan IFRS dalam satu model yang sama. Model kedua menambahkan indeks pengungkapan modal intelektual yang dihitung berdasarkan analisis konten. Kedua model tersebut kemudian dioperasikan pada masing-masing negara secara terpisah. Hasil penelitian ini menunjukkan bahwa efek modal intelektual berbeda-beda antar industri dan antar negara. Rata-rata pengungkapan modal intelektual lebih tinggi pada industri nontradisional dan di negara Inggris dan Australia. Temuan ini juga bisa diartikan 
bahwa hubungan antara pengungkapan modal intelektual dengan harga saham hanya berlaku pada industri spesifik dan negara spesifik. Salah satu temuan inti dari penelitian ini adalah efek moderasi dari pengungkapan modal intelektual berlaku hamper di seluruh negara. Jika dianalisis lebih spesifik efek moderasi yang paling kuat ada pada variable nilai buku yang menegaskan bahwa investor mengaitkan nilai modal intelektual kedalam analisis neraca perusahaan. Walaupun penerapan IFRS tidak selalu konsisten antar negara sampel, penelitian ini mampu memberikan gambaran mengenai peluang factor kenaikan relevansi nilai akibat pengungkapan modal intelektual. Investor tidak mesti mempertimbangkan informasi yang bersifat numeric saja melainkan perlu mempertimbangkan informasi kualitatif lainnya seperti modal intelektual beserta luas pengungkapannya.
3. Value relevance of earnings and cash flows during the global financial crisis (Bepari et al., 2013)

Tujuan penelitian ini adalah untuk mengidentifikasi kenaikan relevansi nilai dengan mempertimbangkan pengaruh aliran kas perusahaan. Konsep relevansi nilai yang popular hanya melibatkan "perwakilan" dari dua laporan keuangan saja. Aliran kas operasi merupakan salah satu angka penting dalam pertimbangan investor dan kinerja perusahaan. Dengan mengambil sampel di pasar modal Australia pada periode 2004-2009. Empat model penelitian dibuat untuk menguji hipotesis yang ada. Hasil penelitian ini menunjukkan bahwa arus kas operasi juga memiliki relevansi nilai. Walaupun menunjukkan hasil yang signifikan, nilai laba terbukti masih memiliki pengaruh yang lebih kuat dibandingkan dengan arus kas operasi.

Temuan menarik dalam penelitian ini menunjukkan pada 
periode krisis ekonomi global (2008/2009), relevansi nilai laba perusahaan masih lebih tinggi dibandingkan nilai arus kas operasi maupun nilai buku perusahaan. Dengan adanya penelitian ini, debat klasik antara kekuatan arus kas operasi dan laba perusahaan mendapatkan opini empiris tambahan yang lebih mengedepankan nilai laba perusahaan. Sifat superior laba dibandingkan arus kas operasi terbukti relevan di Australia dan dapat digunakan sebagai pembuktian lainnya di negara lain.

4. Have financial statements lost their relevance? Empirical evidence from the frontier market of Kuwait - (Alfraih, 2016)

Walaupun dalam tiga artikel sebelumnya relevansi nilai terjadi namun seiring berjalannya waktu, relevansi nilai menunjukkan penurunan/kemerosotan dalam menjelaskan nilai perusahaan. Tujuan penelitian ini adalah menginvestigasi isu tersebut di pasar modal Kuwait selama rentang dua dekade (19942014). Konsisten dengan penelitian relevansi nilai, penelitian ini menggunakan dua variabel utama yaitu nilai buku dan laba perusahaan. Total terdapat 2.490 perusahaan yang akan diregresikan secara time series selama dua puluh tahun. Hasil penelitian menunjukkan bahwa relevansi nilai terjadi sepanjang periode penelitian. Bahkan nilai R2 pada tahun 2000 mencapai 77,1\%. Rata-rata nilai R2 adalah 54,6\% yang mana menunjukkan nilai yang tidak buruk. Baik dari nilai buku maupun nilai laba menunjukkan tingkat signifikansi yang tinggi (dibawah 0,01) selama hamper 20 tahun. Penelitian ini membuktikan bahwa relevansi nilai sangat kuat terjadi di pasar modal Kuwait. Namun penelitian ini membuktikan adanya kemerosotan sesuai dugaan peneliti. Sepanajang 20 tahun tren yang terlihat menunjukkan relevansi nilai menunjukkan penurunan 
kebermanfaatannya. Lebih jauh lagi kemerosotan paling dalam lebih dialami oleh nilai laba dibandingkan nilai buku.

5. The accounting value relevance of earnings and book value: Tunisian banks and financial institutions - (Ahmadi \& Bouri, 2018)

Jika pada umumnya dalam beberapa topik tertentu sampel industri keuangan dikeluarkan dalam sampel penelitian, maka topik relevansi nilai adalah salah satu topik yang masih relevan dan aplikabel pada industri keuangan. Penelitian ini dilaksanakan di industri keuangan yang ada di Tunisia. Periode yang dipilih ialah tahun 2010-2015 dengan total perusahaan hanya 24 emiten saja. Terdapat tiga model yang akan diuji yang merupakan model relevansi standar antara lain model relevansi nilai buku, model relevansi nilai laba dan model relevansi laba dan nilai buku.
Hasil penelitian ini menunjukkan bahwa relevansi terjadi pada seluruh model penelitan yang kembali menegaskan konsep dan teori dari relevansi nilai itu sendiri. Nilai R2 yang menjadi ukuran keukuatan relevansi menunjukkan nilai 0,$20 ; 0,45$; dan 0,51 relatif secara berturutturut terhadap model penelitian. Relevansi yang rendah pada nilai laba menunjukkan investor lebih mengutamakan informasi neraca dibandingkan informasi laba rugi. Selain menguji sampel industri keuangan secara keseluruhan, penelitian ini memiliki analisis lanjutan dengan memisahkan industri keuangan menjadi industri bank dan industri keuangan lainnya. Hasil penelitian masih menunjukkan relevansi nilai pada kedua kelompok namun nilai R2 industri bank lebih tinggi $5,29 \%$ dibandingkan industri keuangan lainnya. Dengan demikian, industri perbankan memiliki relevansi nilai yang lebih tinggi 
dibandingkan industri keuangan lainnya.

6. On the value relevance argument: do market participants place a premium on future prospects of the firm? (Avwokeni, 2018)

Tujuan penelitian ini adalah untuk menguji model Ohlson (1995) dan model Myers (1999) mengenai relevansi nilai. Secara khusus baik Ohlson maupun Myers beragumen bahwa prospek masa depan merupakan aspek yang tidak muncul dalam laporan keuangan. Jika partisipan pasar modal memperoleh premium pada prospek masa depan perusahaan maka model Ohlson dapat diterima. Penelitian ini dilaksanakan di Nigeria dengan memanfaatkan momen adopsi IFRS kedalam model penelitiannya. Terbagi dua periode yaitu 2010-2011 dimana masih menggunakan standar akuntansi domestic dan 20132014 yang telah menerapkan standar akuntansi IFRS.

Hasil analisis menunjukkan dukungan kepada argument
Ohlson dan Myers. Investor ternyata juga mempertimbangkan aspek-aspek lain dalam laporan keuangan dalam membentuk persepsi investasi. Aspek tersebut berupa hubungan terhadap masyarakat atau komunitas, tahapan pengembangan produk baru, dan siklus hidup produk perusahaan. Hasil ini merupakan rekomendasi yang baik bagi IASB untuk memasukkan metrik yang menunjukkan prospek masa depan perusahaan dalam system pelaporan keuangan perusahaan dan temuan ini menegaskan bahwa terdapat item-item yang tidak tersedia dalam laporan keuangan untuk memprediksi relevansi nilai secara lengkap.

7. Value relevance of earnings and book values in the Qatari Stock Exchange - (Almujamed \& Alfraih, 2019)

Hasil temuan yang sama menunjukkan bahwa relevansi nilai telah menurun secara konsisten sepanjang periode. Penelitian ini dilakukan pada pasar modal di atar periode 
2012-2016 untuk menguji model Ohlson (1995) terkait hubungan nilai buku dan laba terhadap harga saham. Terdapat dua hipotesis yang ingin diketahui yaitu apakah secara terpisah relevansi nilai dari laba dan nilai buku mengalami kenaikan selama periode 2012-2016 di pasar modal Qatar.

Hasil pengujian terhadap 215 sampel menunjukkan bahwa relevansi nilai baik nilai buku dan laba menunjukkan hasil pengujian yang signifikan (dibawah 0,001) untuk setiap periode penelitian. Hasil ini menunjukkan bahwa investor tetap memperhatikan nilai akuntansi dalam keputusan investasi. Namun sama halnya dengan temuan penelitian sebelumnya koefisien determinasi mengalami penurunan yang konsisten. Dari 2012 hingga 2016 secara berturut-turut nilai koefisien determinasi yang muncul dari model relevansi nilai adalah 0,$711 ; 0,744 ; 0,733 ; 0,621$; dan 0,595. Hasil ini menegaskan bahwa kebermanfaatan informasi laporan keuangan menjadi kurang optimal dan investor modern mulai mempertimbangkan informasi lain sebagai pertimbangan investasi.

8. The value relevance of $R \& D$ and free cash flow in an efficient investment setup: Evidence from Chinese A-listed firms - (Bin Khidmat et al., 2019)

Salah satu kombinasi unik dalam model relevansi nilai adalah mengikutsertakan aliran kas bersih (FCF) dan item riset dan pengembangan (R\&D). Tujuan dari kombinasi ini adalah menguji apakah FCF dan R\&D memiliki relevansi nilai terhadap tahapan siklus hidup. Penelitian ini dilaksanakan di perusahaan yang terdaftar kategori A dalam Pasar Modal China dalam rentang 2008-2016. Terdapat empat model relevansi nilai yang diuji terkait dengan hipotesis yang diajukan.

Hasil penelitian menunjukkan bahwa item kas bebas dan riset dan pengembangan memiliki relevansi nilai untuk sampel keseluruhan. Efek yang 
dimunculkan dua item ini juga positif dalam mendukung relevansi nilai model Ohlson (1995). Investor terbukti juga mempertimbangkan aspek $R \& D$ yang menyesuaikan iklim bisnis di China yang berkembang pesat. Analisis tambahan juga

\section{SIMPULAN}

Tujuan penelitian ini adalah menelusuri dan mensintesis penelitian-penelitian yang terkait dengan topik relevansi nilai. Temuan dari penelitian ini sendiri adalah untuk menarik kesimpulan berdasarkan temuan penelitian sebelumnya dan menjawab pertanyaan seberapa relevan relevansi nilai sekarang. Studi relevansi nilai masih menjadi topik yang popular walaupun sudah berusia 20 tahun. Dari berbagai hasil penelitian ada banyak hal yang dapat disimpulkan terkait relevansi nilai sebagai suatu konsep dan teori. Pertama relevansi nilai memang benar-benar terbukti secara empiris. Dari artikel yang dikutip dalam penelitian ini seluruh artikel membuktikan secara empiris relevansi nilai terjadi dihampir 10 negara yang diteliti oleh 8 penelitian. Investor masih menggunakan informasi keuangan yang ada dalam laporan menunjukkan bahwa investor lebih memberikan respon terhadap laba dibandingkan nilai buku perusahaan. Signifikansi faktor FCF dan R\&D dapat dilihat dari nilai koefisien determinasi yang bernilai 0,46.

keuangan untuk pengambilan keputusan investasi. Walaupun relevansi nilai terjadi, terdapat fakta yang perlu menjadi bahan pertimbangan regulator dalam menyusun standar pengukuran informasi keuangan karena relevansi nilai informasi akuntansi terus mengalami penurunan sepanjang satu dekade ke belakang. Penurunan ini menunjukkan angka akuntansi kehilangan kekuatan dalam memprediksi nilai perusahaan yang biasa diukur dengan harga saham perusahaan masing-masing. Jika hal ini dibiarkan maka informasi akuntansi dapat turun kasta menjadi "informasi kedua" (secondary information). Dengan membandingkan biaya regulasi yang signifikan di seluruh negara maka regulator perlu memastikan bahwa informasi yang dikeluarkan oleh perusahaan memiliki relevansi yang tinggi. Riset-riset relevansi nilai perlu 
terus memperbaharui data yang ada dan melanjutkan model penelitian seperti ini untuk memastikan informasi penurunan/kenaikan relevansi nilai sebagai sinyal bagi seluruh pihak yang berkepentingan. Kontribusi dari

\section{DAFTAR PUSTAKA}

Ahmadi, A., \& Bouri, A. (2018). The accounting value relevance of earnings and book value: Tunisian banks and financial institutions. International Journal of Law and Management, 60(2), 342-354. https://doi.org/10.1108/IJLMA11-2016-0131

Alfraih, M. M. (2016). Have financial statements lost their relevance? Empirical evidence from the frontier market of Kuwait. Journal of Advances in Management Research, 13(2), 225-239. https://doi.org/10.1108/JAMR06-2015-0043

Almujamed, H. I., \& Alfraih, M. M. (2019). Value relevance of earnings and book values in the Qatari Stock Exchange. EuroMed Journal of Business, 14(1), 62-75. https://doi.org/10.1108/EMJB02-2018-0009

Avwokeni, A. J. (2018). On the value relevance argument: Do market participants place a premium on future prospects of the firm? Journal of Financial Reporting and Accounting, 00-00. penelitian ini dapat dilihat dengan menjawab judul penelitian ini yaitu "seberapa relevan relevansi nilai?" Jawaban berdasarkan telaah literatur yang telah dilaksanakan adalah "cukup relevan dan perlu diawasi"

https://doi.org/10.1108/JFRA02-2017-0012

Ball, R. and Brown, P. (1968), “An empirical evaluation of accounting income numbers", Journal of Accounting Research, Vol. 6 No. 2, pp. 169-178.

Barth, M.E., Beaver, W.H., Hand, J.R.M. and Landsman, W.R. (1999), "Accruals, cash flows and equity values", Review of Accounting Studies, Vol. 4 Nos 3/4, pp. 205-229.

Barth, M.E. (2000), "Valuation-based accounting research: implications for financial reporting and opportunities for future research", Accounting \& Finance, Vol. 40 No. 1, pp. 732.

Bepari, K., Rahman, S. F., \& Taher Mollik, A. (2013). Value relevance of earnings and cash flows during the global financial crisis. Review of Accounting and Finance, 12(3), 226-251. https://doi.org/10.1108/RAFMay-2012-0050 
Bin Khidmat, W., Wang, M., \& Awan, S. (2019). The value relevance of R\&D and free cash flow in an efficient investment setup: Evidence from Chinese A-listed firms. Asian Journal of Accounting Research, AJAR10-2018-0035.

https://doi.org/10.1108/AJAR10-2018-0035

Charitou, A., Clubb, C. and Andreou, A. (2001), "The effect of earnings permanence, growth and firm size on the usefulness of cash flows in explaining security returns: empirical evidence for the UK", Journal of Business Finance \& Accounting, Vol. 28 Nos 5/6, pp. 563-594.

Dudovskiy, J. (2018). The Ultimate Guide to Writing a Dissertation in Business Studies: A Step-byStep Assistance.

Francis, J. and Schipper, K. (1999), "Have financial statements lost their relevance?", Journal of Accounting Research, Vol. 37 No. 2, p. 319.

Gumanti, Tatang Ari dan Elok Sri Utami, (2002), Bentuk Pasar Efisien dan Pengujiannya. Jurnal Akuntansi dan Keuangan, Volume 4, Nomor. 1, Hal 65-66.

Habib, A. (2008), "The role of accruals and cash flows in explaining security returns: evidence from New Zealand", Journal of International Accounting, Auditing and Taxation, Vol. 17 No. 1, pp. 51-66.

Jamaluddin, A., Mastuki, N., \& Elmiza
Ahmad, A. (2009). Corporate Governance Reform and the Value Relevance of Equity Book Value and Earnings in Malaysia. Journal of Financial Reporting and Accounting, 7(2), 41-59.

https://doi.org/10.1108/1985251 0980000003

Kuswanto, R. (2017). Relevansi Nilai Informasi Akuntansi Dengan Model Ohlson. Jurnal Ilmiah Akuntansi dan Finansial Indonesia, 1(1), 45-58. https://doi.org/10.31629/jiafi.v1i 1.1238

Lev, B. (1989), "On the usefulness of earnings and earnings research: lessons and directions from two decades of empirical research", Journal of Accounting Research, Vol. 27, Supplement,pp. 53-192.

Ohlson, J.A. (1995), "Earnings, book values, and dividends in equity valuation", Contemporary Accounting Research, Vol. 11 No. 2, pp. 661-687

Vafaei, A., Taylor, D., \& Ahmed, K. (2011). The value relevance of intellectual capital disclosures. Journal of Intellectual Capital, 12(3), $\quad$ 407-429. https://doi.org/10.1108/1469193 1111154715 